\title{
STATUS OF GULAG RESEARCH IN THE UNITED STATES, WITH SPECIFIC ATTENTION TO THE HUNGARIANS
}

\author{
STEVEN BÉLA VÁRDY \\ Duquesne University \\ Pittsburgh, PA, USA \\ E-mail: svardy@aol.com
}

\begin{abstract}
The twentieth century was undoubtedly the bloodiest hundred years in the history of humanity. In this final century of the second millennium more humans suffered from various state-sponsored programs and institutions of mass murder than during the whole stretch of written century. In the twentieth century tens of millions of humans fell victim to these so-called "redeeming" religious and political ideologies. The bloodiest of these ideologies included: (1) an extreme form of nationalism that culminated in racism; (2) applied Marxism that hid under the mantle of Bolshevism and Stalinism; (3) national socialism that manifested itself in Fascism and Nazism; and finally (4) the recently emerging Fundamentalist Islam that attempted to tear down the structure and achievements of Western Christian Civilization. These "redeeming ideologies" competed against each other in their efforts to torture, torment, and annihilate tens of millions, perhaps hundreds of millions of human beings. The best known among these mass exterminations is undoubtedly the Holocaust, which resulted in the torturous death of six million Jews or alleged Jews, among them several hundred-thousand Hungarians. This centrally planned and meticulously executed extermination process is so well known that nowadays it is part of general human consciousness everywhere in the world. Sadly, this does not apply to the other 20th-century mass extermination known as the Gulag, which is not part of that consciousness. In point of fact, one still encounters scholars who don't even believe that the Gulag had ever existed. While Holocaust-research is pursued in the United States at several dozen universities, museums, libraries and various other research centers, this does not apply to the Gulag, which is hardly known to the general public. This is also true for American university students, of whom - based on my own experiences - less than five percent is aware of this modern form of slavery and mass extermination. The goal of this paper is to summarize briefly the type of Gulag-research pursued in the United States, which - in absence of specialized research institutes - is pursued mostly by individual scholars. Toward the end of this study, reference is also made to the "Gulag-consciousness" and "Gulag-research" in Hungary - which also leaves much to be desired.
\end{abstract}

Keywords: Gulag, artificial famine, black book of communism, bolshevism, communism, fascism, Holocaust, Kolyma, Stalinist purges 
The twentieth century was undoubtedly the bloodiest hundred years in the history of humanity. In this final century of the second millennium more humans suffered from various state-sponsored programs and institutions of mass murder than during the whole stretch of written century. In the twentieth century tens of millions of humans fell victim to these so-called "redeeming" religious and political ideologies. The bloodiest of these ideologies included: (1) an extreme form of nationalism that culminated in the triumph of racism; (2) applied Marxism or communism that hid under the mantle of Bolshevism and Stalinism; (3) national socialism that manifested itself in the form of Fascism and Nazism; and finally (4) the recently emerging Fundamentalist Islam - in President George W. Bush's words "Islamic Fascism" - that attempted (and still attempts) to tear down the structure and achievements of Western Christian Civilization. These "redeeming ideologies" competed against each other in their efforts to torture, torment, and annihilate tens of millions, perhaps hundreds of millions of human beings.

The best known among these mass exterminations is undoubtedly the Holocaust, which resulted in the torturous death of six million Jews or alleged Jews, among them several hundred-thousand Hungarians. This centrally planned and meticulously executed extermination process is so well known that nowadays it is part of general human consciousness everywhere in the world.

Sadly, this does not apply to the other 20th-century mass extermination known as the GULAG, which is not part of that consciousness. As the well-known Gulag-researcher, Tamás Stark, wrote in one of his relevant studies, there are historians who don't even acknowledge the existence of the Gulag. In one of the conferences he attended, entitled: "Gulag - Myth and Reality", Stark encountered scholars who denied the very existence of this Stalinist institution of mass murder. ${ }^{1}$ This denial was partially the result of the fact that during the 1930 s and 1940s the majority of Western intellectuals were enamored with Stalin; and partially of the post-World War II rivalry between the two superpowers that took the form of the Cold War. As summarized by the other noted Gulag-researcher, Ágnes Gereben, following the Second World War "the competition among the members of the erstwhile anti-Fascist coalition was by far the most important question". ${ }^{2}$ Given this reality, none of the Western political leaders were really interested in dealing with the Stalinist terror and its impact upon the lives of tens of millions of victims.

As noted below, the Holocaust was a unique phenomenon. For this very reason it is not very fortunate to compare it with the Soviet Gulag. But similarly to the Holocaust, the Gulag also resulted in the torturous death of millions of human beings. Thus, their suffering should also be part of general human consciousness. To question its existence is like denying the existence of the Holocaust, which is a punishable deed in sixteen European countries. ${ }^{3}$ It was his denial of the Holocaust that landed the British historian, David Irving, in an Austrian prison. ${ }^{4}$ (To the best 
of my knowledge, there are only two countries - France and Hungary - that have laws not only against the denial of the Holocaust, but also about the questioning of the existence of the Gulag.)

There were a good number of liberal Western intellectuals who spoke up against Irving's imprisonment in the name of the freedom of speech. In their view, Irving's incarceration could only help the extreme right, because it would make the forlorn British historian into a heroic martyr. The noted American publicist, Christopher Hitchens, gave vent to this view as follows: "Free speech Über Alles. Even for David Irving" [Freedom of Speech over everything. Even for David Irving]. ${ }^{5}$

The lack of common Hungarian consciousness about the Gulag is best demonstrated by the lack of treatment of this Bolshevik-inspired mass extermination in most histories of 20th century Hungary. Even the word "Gulag" is missing from such prominent handbooks as Magyar szókincstár [Hungarian Dictionary] (1999), and eleventh edition Magyar helyesírás szabályai [Rules of Correct Hungarian Spelling] (2000) published by the Hungarian Academy of Sciences. As a result of these omissions not even educated Hungarians know very much about the Gulag. And this is even more true about the semi-educated masses, who know virtually nothing about this system of mass slavery and mass eradication of many millions. Thus, we should not be surprised when the average Hungarian, who was approached for financial support by the directors of the Gulag Foundation, refuse to contribute because they think that the donated money would support a "Kulák Association". ${ }^{6}$ In other words they routinely mix up the word "Gulag" with the word "Kulák" - the latter being the so-called "rich peasants", who became the primary victims during Stalin's collectivization drive in the early 1930s..

This lack of knowledge about the Gulag is equally evident in the United States. This can be demonstrated by my own experience at Duquesne University, where I have been teaching for over four decades. Ever since my wife and I began our Gulag research in the year 2003, I quizzed my students at the start of all of my classes about their knowledge of the Holocaust and the Gulag. In a class of forty students every single one of them knew the essence of the Holocaust, but only two or three knew something about the Gulag. And even they could barely identify it as an institution of oppression and mass slavery. All they knew that it was somehow connected with the Soviet Union. ${ }^{7}$

\section{The Essence of Communism and Nazism}

According to a number of disenchanted Western intellectuals who after 1956 left the fold of the Communist Party, there is a very close relationship between Communism and Nazism. This is evident from the life and career of Alain Besancon, 
whose views are detailed in his work Le malheur de siécle [The Century of Horrors] (1998). His views are summarized by the translator and editor of the English version of his volume as follows:

\begin{abstract}
While Nazism is recognized, justifiably, as the very embodiment of evil, communism somehow benefits from a kind of collective amnesia. It shocks or at least surprises no one today to hear it said that Soviet communism was a good idea that turned out badly, whereas, of course, it would be unthinkable to make similar observations about Hitler's regime. ${ }^{8}$
\end{abstract}

But as Besancon demonstrated in his brilliant analysis of the essence of these two allegedly rival ideologies, there is a great deal of similarities between them. In other words,

\begin{abstract}
a sober and unblinking consideration of the two cases, side by side, reveals pervasive similarities. ... Even though the Nazis carried crime to the level of intensity perhaps unequaled by communism, one must nevertheless affirm that communism brought about a more widespread and deeper moral destruction. ${ }^{9}$
\end{abstract}

Therefore we have to accept the thesis that "Nazism and communism are criminal. But they are equally criminal". ${ }^{10}$ Here we must remind the reader that today Alain Besancon (b. 1932) is one of France's most recognized thinkers and intellectual historians, who, between 1951 and 1956, was a member of the French Communist Party. As such he not only studied, but also lived this destructive ideology.

\title{
The Situation in the United States
}

As pointed out above, even though the Gulag system impacted Hungary directly, there is still a general lack of knowledge about the nature of the forced labor system and how it affected the Hungarians. It shouldn't be a surprise to anyone that a similar lack of knowledge also exists in the United States, which by virtue of its power-position remained unaffected by the Stalinist terror. Also important were the following considerations: (1) the geographical distance between the two superpowers, (2) their somewhat unnatural alliance against the Nazi Germany during World War II, (3) their confrontation during the Cold War, which suppressed all interests in the Gulag, and finally (4) Stalin's death in 1953 and the subsequent dissolution of the Soviet slave labor camps. In consequence of these developments - while keeping the memory of the Holocaust alive via national and international research centers, archives, and libraries became a number one priority of 
many Western intellectuals - the fate of the victims of the Gulag system and Stalinist terror in general were gradually forgotten.

True, the appearance of Alexander Solzhenitsyn's Gulag Archipelago in 1973 did shake up the consciousness of the world somewhat. Yet, not even this agonizing portrayal of the Soviet Gulag was able to lift the Stalinist terror system out of obscurity to a point where it would have rivaled the position of the Holocaust. There were some Stalin-worshiping Marxist intellectuals who went so far as to belittle and trivialize Solzhenitsyn's work. By far the most condemnable among these Stalin-worshiper was the Nobel-laureate Chilean poet, Pablo Neruda (1904-1973), who was among the first to be awarded a Stalin prize. Upon reading Solzhenitsyn's Gulag Archipelago, Neruda declared that everything the Russian writer had described pales besides all the good which "this small man with a huge moustache" [Stalin] has done in the interest of humanity. ${ }^{11}$

As noted by Hungarian-American political scientist, Paul Hollander,

Neruda's long-standing commitment to the support of the Soviet regime precluded sympathy with Solzhenitsyn's fate: it also prompted him to try to trivialize the persecution of Solzhenitsyn by calling it a 'big bore'. 12

In those days the Western World was inundated with the Neruda-like intellectuals in whose eyes Stalin was a canonized genius. Because of their total dedication to Stalin as the leader of the communist world they were not interested in knowing anything about the nature of the Soviet Gulag, nor about the fate of the many millions who suffered there and fell victim to this instrument of political oppression. The worst among them was Neruda who retained his original dedication even after 1956, which saw Khrushchev's unmasking of Stalin, and the unexpected eruption of the anti-communist and anti-Soviet Hungarian Revolution.

To the best of my knowledge - in contrast to the Holocaust, which is represented in the United States by dozens of research centers and museum - there is not a single research institute or professorship in the United States that deals with the history of the Gulag. For this reason the development of the Gulag and its study in the United States can only be treated on the basis of the activities and publications of individual scholars.

From the point of view of American Gulag scholarship the most important practitioners of this research are two personalities who are separated from each other by nearly half century. They are Robert Conquest (b. 1917) and Anne Applebaum (b. 1964). In addition to them we can also mention a number of other scholars, a few of whom may not be Americans, but came to be known to the world primarily through their English language publications, mostly in the United States. In addition to the writings of a few native scholars, their works also became part of American Gulag research. 
The pioneer American Gulag-researcher is the currently 95 year old Robert Conquest, who is still an active member of Stanford University's Hoover Institution - the largest Russian research center in the United States. ${ }^{13}$ Son of an American father and a Norwegian mother, and having been brought up in Britain, this Anglo-American historian has authored over two dozen books on the Soviet Union, and on the Soviet slave labor system established by Lenin and perfected by Stalin. Conquest's most influential work is The Great Terror, originally published in 1968. This work was the first truly scholarly description of the Stalinist purges in the period between 1934 and 1939, which resulted in political trials, mass executions, mass deportations, and the filling up of the Gulag slave labor camps. According to Conquest these Stalinist purges were responsible for the death of about 20 million, mostly innocent human beings. He based his work partially on Soviet historical sources following the relaxation under Khrushchev (1953-1964), and partially on the information derived from Soviet immigrants, who either fled or were permitted to leave the Soviet Union.

The Great Terror was republished in a revised edition in $2007 .{ }^{14}$ In this work, based on significantly more sources, Conquest lowered his estimate of the number of Stalin's victims during the period of the purges to about 13-15 million. What is the truth? Probably no one will ever know. This is best demonstrated by the widely divergent figures circulated about the victims of Lenin and Stalin. Just to mention a few: According to Alexander Solzhenitsyn, the author of the Gulag Archipelago (1973) - those who passed through the Gulag camps numbered around 60 million. The noted British historian, Norman Davis, believes their numbers to have been 50 million. General Dimitri Volkogonov, the head of a Soviet historical research institute, swears by 45 million. The dissident historian, Roy Medvedev speaks of 40 million. Robert Conquest originally believed their number to have been between 20 and 30 million. The prestigious Encyclopedia Britannica speaks of 20 million, The Black Book of Communism of 20 million, Anne Applebaum of 17-18 million, and the British economic historian with Marxist sympathies of 10-11 million. This is the reality that a Gulag-researcher finds himself confronted with when trying to write something worthwhile about this institution of political oppression. Although on a smaller scale, the situation is similar to the Hungarian victims of the Gulag, whose numbers also diverge among serious Gulag-researchers. $^{15}$

Naturally, historians who are dedicated Marxists are strong at work trying to lower the number of the victims, while also attempting to humanize the functioning of the Gulag system. Sadly, this is true even for Hungary that was one of the primary non-Soviet states of Stalinist oppression. Even in Hungary there are a number of historians who still promote Stalinism, and for this reason they try to minimize the viciousness of the Gulag system and thus lower the number of Hungarians who fell victim to this Stalinist terror. 
The most noted Gulag-minimizer among Hungarian historians is Tamás Krausz, Professor of History at the University of Budapest [ELTE] and the Director of the Institute of Russian Studies at that institution. He is also the same historian who in 2005 accused Professor Robert Conquest of being a political propagandist in the pay of Ukrainian nationalists. Krausz did this partially because he believes that Conquest's "secret goal" is to "equate Nazi genocide with the Gulag". This, however, is a forcible reinterpretation of Conquest's scholarly views, activities, and publication, for he never made such a statement. At the same time such a statement was made by the best known Gulag-researcher, Anne Applebaum, in a documentary film [DVD] made in 2004, and entitled "Siberia". While being interviewed she stated that in her views "The Gulag and the Holocaust belong in the same category of historical events". ${ }^{16}$

I do not agree with Applebaum's above quoted statement, for I regard the Holocaust as a unique phenomenon. This mass extermination was the only event in human history, wherein the leaders of a political regime decided to kill everyone who in any way could be classified as a Jew. (This also applies to the Gypsies, homosexuals, and the physically impaired.) One can hardly doubt that the Gulag system was responsible for many more deaths than the Holocaust. But the creators of the Gulag never made a decision to exterminate every single member of a specific ethnic, national, or religious group. In the case of the Gulag one's nationality, ethnicity, or ideology made no difference. They exploited, tortured, and exterminated everyone who in any way stood in their way. And this applied even to the founding fathers of the Soviet Union, as well as to the executors of Stalin's murderous plans for mass extermination. The best examples of the former include Leon Trotsky (1879-1940), Grigory Y. Zinoviev (1883-1936), Lev B. Kamenev (1883-1936), and Nicholas I. Bukharin (1888-1938); while the best examples of the latter are the two consecutive Directors of the Soviet Secret Police [NKVD], Genrikh G. Yagoda (1891-1938; tenure in office 1934-1936) and Nikolai Yezhov (1895-1939; tenure in office 1936-1938), all of whom fell victim to the Stalinist purges. ${ }^{17}$

It is this phenomenon that distinguished the Holocaust from the Gulag, and which makes the former into a unique phenomenon. And this is recognized by most Gulag researchers, including Professor Robert Conquest - even if occasionally he draws a parallel between these to institutions of mass extermination.

It should also be mentioned here that Gulag-deniers also exist in the United States. The most notorious of these deniers is Grover Furr, who is a Professor of English at Montclair State University and a dedicated Stalinist. His most notorious work is his study entitled "Stalin and the Struggle for Democratic Reform". ${ }^{18}$ Furr's description of Stalin makes this greatest of mass murderers (along with Hitler and Mao Tse-tung) into a humanitarian democratic leader. And he does this 
with a man who declared that: "The death of one man is a tragedy, the death of millions is statistics".

\section{Anne Applebaum, and Gulag-Consciousness in America}

Anne Applebaum was born just four years before the appearance of Robert Conquest's book The Great Terror (1968). Yet today she is the best known Gulag-researcher who produced a book that rivals in importance Conquest's above mentioned volume.

In contrast to Robert Conquest, who had always been attached to a university or an institution of scholarly research, Applebaum became a Gulag researcher after being trained as a publicist or journalist. She learned French, Polish and Russian, and during the 1990s she moved to Warsaw, Poland, where in 1992 she married Radoslaw Sikorski, a member of the Polish intellectual and social elite, and since 2007 Poland's Foreign Minister. ${ }^{19}$ Her book, Gulag. A History is a major synthesis of the history and functioning of the Soviet Gulag system. It appeared in 2003, and in 2004 it earned for her a Pulitzer-prize.

Applebaum's book was received with great ovations, and was praised highly by such prominent public figures as President Nixon's Secretary of State Henry Kissinger, President Carter's National Security Adviser, Zbigniew Brzezinski, as well as her predecessor in Gulag research Professor Robert Conquest. Based on their comments it is evident that with her Gulag volume Anne Applebaum has produced a significant scholarly work. Her book was published in many tens of thousands of copies, and spread through the whole English-speaking world. And in translation it was disseminated to various non-English speaking countries. For the first time since Solzhenitsyn's Gulag Archipelago (1973) it aroused interest in the Stalinist system of mass extermination. Knowledge about the Gulag began to penetrate even into American consciousness, although still far from the level of the Holocaust.

\section{A Few Other Gulag Researchers}

In the period between Conquest's The Great Terror (1968) and Anne Applebaum's Gulag, A History (2003) there were a number of others who published scholarly works on the history of the Gulag. But these monographs never left the limits of the scholarly world, wherefore their impact was also limited.

Some of the important Gulag books that appeared in English from the pens of non-Americans included (1) Avraham Shifrin's The First Guidebook to Prisons and Concentration Camps in the Soviet Union (1980), (2) Colin Thubron's In Si- 
beria (1999), (3) Nanci Adler's The Gulag Survivor (2002), (4) Oleg V. Khlevniuk's The History of the Gulag (2004), and (5) the multi-authored The Black Book of Communism (1999).

In his book The First Guide to Prisons and Concentration Camps the Russian emigré historian Avraham Shifrin identifies and describes over two-thousand Soviet penal institutions that existed in the Soviet Union even in $1980 .{ }^{20}$ Some of them were specifically for the incarceration of common criminals. But the majority of the enumerated institutions were the homes of political prisoners. And this, almost three decades after the death of Joseph Stalin, which allegedly signaled the beginning of the dismantlement of Gulag slave labor camps. But as we know from other sources, the final elimination of the Gulag camps was completed only during the period of Mikhail Gorbachev (1985-1991).

The volume In Siberia was authored by the British author and traveler Colin Thubron, who visited the remnants of many former Gulag camps throughout the erstwhile Soviet Union. ${ }^{21}$ Among others, he surveyed scores of penal colonies in such remote regions as Tobolsk, Vorkuta, Norilsk, Kabarovsk, Yakutia, and even the very remote province of Kolyma. The latter was the most dreaded Soviet penal colony, which had been established specifically to extract gold from recently discovered gold deposits. In Kolyma Thubron first visited its capital city of Magadan, from where he took the "Road of Bones" up to the mines, where very few prisoners survived. During the 1930s and 1940s between two and three million innocent human beings perished there, and their bones can be found on both sides of the three-hundred miles long Road of Bones that connects Magadan with the gold mines in the north. In one of the penal camps in Vorkuta, Thubron found a large rock on which the following message was scrawled: "I was exiled [here] in 1949, and my father died here in 1942. Remember us."22 Thubron's writing is very moving and portrays vividly the misery of the millions of victims of Stalin's terror regime. Fortunately Thubron visited the remnants of these camps when they were still visible - at least partially. Soon, however, even these remnants will disappear. Their absence will help eradicate the memory of Stalin's crimes, including the mass extermination of many tens of millions of innocent victims.

I would also like to mention that in 2004 the Hungarian film director and producer, Zoltán Szálkai, also visited Kolyma. He walked on the Road of Bones from Magadan to the gold mines, and filmed some of the same Gulag camps that had been seen and recorded by Colin Thubron a few years earlier. His resulting documentary entitled "Walking on the Gulagland. Kolyma" is the result of his visit to this forbidden land of terror. Szálkai's documentary is a brave effort to portray the misery of these death camps. Yet, not even his films can describe the suffering of the prisoners who knew that their only path lead to agony and ultimately to excruciating death in that land of hopelessness. ${ }^{23}$ 
Simultaneously with Thubron's book In Siberia appeared the bulky volume The Black Book of Communism (1999), which had been authored by six French scholars. ${ }^{24}$ The authors of this volume claim that the victims of communism during the period of the existence of the Soviet Union numbered close to one-hundred million, of whom at least twenty million can be attributed to Stalin. (As we have seen, some other scholars claim that the true number of Stalin's victims is closer to forty to sixty million.) If we stick with the figure of 20 million, then - according to the calculations of János Rózsás - one to two percent (i.e., 200,000 to 400,000) of the victims were Hungarians, who perished on the Gulag. While these numbers may not seem excessive in light of the overall number of the victims of the Gulag, but in the case of a small nation such as the Hungarians they are in fact huge numbers. One to two per cent in their case would be between 30 to 60 million in the case of Americans, who now number over 300 million. This may explain why in the 850 page Black Book of Communism Hungarians are given only about eight pages. But this is still much more than what they were given in several of the other Gulag volumes that appeared in the 1990s and early 2000s.

Forgetting to mention Hungarians from among the victims of the Soviet Gulag is true for all of the other books that were mentioned above. Thus, Nanci Adler of the of California State University at San Diego, and of the Center for Holocaust and Genocide Studies at the Royal Netherlands Academy of Arts and Sciences, concentrates on the post-World War II period, ${ }^{25}$ specifically on those who suffered and managed to survive the Gulag camps. But she has nothing to say about Hungarians.

This also holds true for Oleg Khlevniuk's volume, The History of the Gulag. From Collectivization to the Great Terror (2004), which deals only with the 1930s, represented by Stalin's transformation of the Russian social and political scene and the extermination of all of his rivals. ${ }^{26}$ According to Khlevniuk, the slave labor camps of the 1930s were basically different from the concentration camps of the 1920s. Stalin's camps were not only the depository of political rivals, but also the prisons of the many millions who had been arrested and condemned simply because Stalin needed unpaid labor for the social and economic transformation of Russia. Sadly, similarly to Adler's monograph, Khlevniuk's book received equally little attention.

\section{Harrowing Books about the Gulag}

In addition to the above volumes, there are a few others that deserve special attention. The two most significant include a book by the Hungarian-born political scientist Paul Hollander (b. 1932) and by the Greek-born British film director, Tim Tzouliadis (b. 1968). 
Paul Hollander left Hungary after the anti-Soviet Hungarian Revolution of 1956. He studied at Princeton and Harvard Universities, and then joined the Department of Political Science at the University of Massachusetts at Amherst. His most important scholarly work is his Political Pilgrims. Travels of Western Intellectuals to the Soviet Union, China, and Cuba, 1928-1978 (1981), wherein he describes the adoration displayed by Western intellectuals toward Stalin. Hollander demonstrates with quotations from the writings of hundreds of Western intellectuals of how they were routinely misled by Stalin's propaganda machine. Instead of recognizing the fact that under Stalin's leadership the Soviet Union had become the huge penal colony where millions were being tortured to death, these "great intellectuals" viewed Stalin's Russia as the land of the future, as an experimentation in Utopia. Among these "great intellectuals" were such noted personalities as Thomas Mann and Gerhard Hauptmann of Germany, Anatole France and André Maurois of France, George Bernard Shaw, H. G. Wells, and Sidney and Beatrice Webb of Britain, Theodore Dreiser and Upton Sinclair of the United States, and scores of others from Western Europe and North America. ${ }^{27}$

Their dedication to Marxism, and their naive hope that under the aegis of this ideology a beautiful and happy Utopian society would emerge has blinded them completely. They were simply unable to recognize the hard reality of the oppressive Stalinist system. They were blind even to the artificial famine created by Stalin that resulted in the miserable death of over six million Ukrainian and Caucasian peasants ${ }^{28}$ creating a situation which ultimately lead even to the practice of cannibalism. ${ }^{29}$ These Western intellectuals were unwilling to acknowledge the existence of thousands of slave labor camps, filled with millions of guiltless human beings. Nor were they willing to recognize the true nature of the political trials of the 1930s, which sent hundreds of Bolshevik founding fathers to the gallows. And all this simply because a Caucasian brigand originally named Dzhugashvili [Stalin] wanted to get rid of all his rivals, and thus become the uncontested and glorified leader of the Soviet Union and of the Communist World. Or as formulated by Paul Hollander, these glorified Western intellectuals were so "favorably disposed toward the [Soviet] regime ... that they could not easily entertain the possibility of being the victims of an elaborate scheme of deception". But this naiveté made them into the willing tools of the totalitarian Stalinist regime, which regime went far beyond the inhumanity of the former Czarist regime. Thus they became the tools of Soviet propaganda. Moreover, during and after World War II a number of them went so far as betrayed their countries by delivering atomic secrets to Stalin's Russia.

Paul Hollander's book was so well received that it has already appeared in four editions, which is unusual for a scholarly monograph. In 2007 he also published a bulky volume entitled From the Gulag to the Killing Fields, which covers the a wide spectrum of countries, and contains sections of the reminiscences of former 
Gulag prisoners. ${ }^{30}$ They include Albanians, Bulgarians, Cambodians, Cubans, Czechs, Ethiopians, Germans, Koreans, Nicaraguans, Poles, Romanians, Vietnamese, Yugoslavs, and also two Hungarians. But they are not the typical Hungarians who have been forcibly deported and exploited, but who managed to survive. The two Hungarians - Paul Ignotus and György Pálóczi-Horváth - were Marxist intellectuals who never suffered in the Gulag, but only in Rákosi's prisons in Budapest. ${ }^{31}$ They became disenchanted with the Rákosi regime, but not with the ideology of Marxism. They certainly do not fit the image of an average Gulag prisoner whose numbers were in the hundreds of thousands, and most of whom were members of the anti-communist working class. Among those who survived many scores have written their memoirs that reflect reality of the Gulag much better than anything these two disenchanted intellectual wrote. ${ }^{32}$

Paul Hollander's writings are strictly scholarly works. This does not quite apply to Tim Tzouliadis's book, The Forsaken (2008), which is more like a movie script. ${ }^{33}$ It describes life of American Gulag prisoners through the life stories of some of those who survived, returned home, and wrote their memoirs after the collapse of the Soviet Union. Tzouliadis's book is unique because until its appearance no one thought that there were Americans in the death camps of the Gulag. Up to the appearance of Tzouliadis's book no one ever imagined that Americans have ended up, suffered and died in Stalin's Gulag. But now, in light of this book, this American tragedy is undeniable.

But how did American citizens end up in the Soviet Union, and then in one of Stalin's dreaded slave labor camps? The roots of this hair-raising development reach back to the start of the "Great Depression" of 1929. This economic crisis began in New York, but then it spread through much of the industrialized world. In consequence of this economic breakdown of Western societies, unemployment became universal in most industrialized countries. Even the formerly envied American society came to be characterized by poverty, destitution, and soup lines. This unexpected economic misery occurred simultaneously with Stalin's first Five-Year Plan, when the Soviet Union was in need of industrial goods, machinery, and trained industrial workers to operate this machinery.

In 1931 the Soviet trading corporation AMTORG - established with the help of the crypto-communists American industrialist, Armand Hammer - began to recruit trained American industrial workers for the Soviet Union. The unemployed workers who volunteered to go with their families were warmly received in the Soviet Union. AMTORG paid for their transit fees, and promised them high salaries, classy apartments, annual vacations, free education for their children, and free medical care. In line with the misled Western intellectuals who believed in Stalin, these American workers were also mislead. They thought that under Stalin's "wise leadership" they would be living in a Utopia, a land characterized by liberty, equality, and fraternity. They were in for great surprise. 
None of the Soviet promises turned out to be true. Within a few years all of these gullible Americans ended up in the Gulag, and most of them remained there permanently. Among their ranks was Lovett Fort-Whiteman (1894-1939), a black American communist, who was one of the founders of the American Communist Party, but who in 1937 still disappeared. ${ }^{34}$ As it turned out, he had been arrested by the NKVD for his "Trockyite deviation". He was deported to a slave labor camp in Khazakstan, and then to Kolyma, where - after many beatings and hunger - he died in 1939. It is worth mentioning that a few years earlier, two white American workers beat up this black communist, for which they were expelled from the Soviet Union. This was their luck. Had they not been ejected from Stalin's Empire, they too would have been taken to the Gulag, and they too would have ended up dead like the unfortunate Fort-Whiteman.

The American workers who have been enticed to migrate to the Soviet Union, soon realized their mistake. They were forced to come to the conclusion that instead of the promised Utopian society they became helpless victims of a totalitarian slave society. Following this realization they made desperate efforts to return to the United States. In doing so they sought the help of the American Embassy headed by Joseph E. Davis (1876-1958), one of F.D. Roosevelt's close political friends. ${ }^{35}$ But Davis was also overawed by Stalin's "greatness" and refused to have anything to do for these unfortunate Americans. He did not want to damage his relationship with "Marshall Stalin" by attempting to help his unfortunate countrymen. Nor did they receive any help from the crypto-communist American intellectuals, who were likewise overawed by the Soviet dictator's "greatness". The latter included the Asian specialist Owen Lattimore (1900-1989) of Johns Hopkins University, ${ }^{36}$ and the Pulitzer Prize winner journalist Walter Duranty (1884-1957) of the New York Times. They too refused help to their fellow Americans in Soviet captivity. And this also applies to the internationally known communist black singer, Paul Robeson (1898-1976), who openly rejected their plea for help. Robeson continued to support Stalin's effort to transform Russian society into a land of Utopia through the utilization of slaves. ${ }^{37}$ This was the fate of thousands of Americans who believed in Stalin and in his promise of creating a land of Utopia in the Soviet Empire.

\section{The Misled Hungarian Victims of Soviet Marxism}

There were a good number of Hungarians who - like their American colleagues believed sufficiently in the salutary nature of Marxism to emigrate to the Soviet Union. In most instances disappointment followed almost immediately. The promised Utopian society turned out to be a land of terror and inhumanity. 
A good example of this situation was the case of Ferenc Róth (1898-1950), who in 1931 emigrated to Stalin's empire with his family, and then fell victim to that empire of terror. Ferenc Róth realized his mistake as soon as his train crossed the Polish-Soviet border, where the Soviet border guards acted rudely, suspiciously, and impolitely. By the time they reached the Moscow train station they were full of fright:

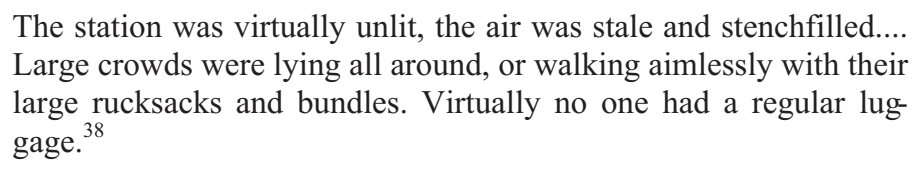

The station was virtually unlit, the air was stale and stenchfilled.... Large crowds were lying all around, or walking aimlessly with their large rucksacks and bundles. Virtually no one had a regular luggage. $^{38}$

Ferenc Róth - whose name in the Soviet Union was changed to Rott - worked for seven years in the wood industry under constant fear, even though he repeatedly proclaimed his devotion to Marxism and to its "infallible great leader" Joseph Stalin. But being a Hungarian, he was viewed as untrustworthy. Then in July 1938 he was arrested and exiled to Kolyma, one of the Soviet empire's most dreaded penal colonies. He lived and died there after twelve years. His occasional contacts with his family were through personal letters, first in Russian (which he hardly spoke), and later in his mother tongue, Hungarian. His younger son, Vladimir, was born in the Soviet Union in 1935, and grew up knowing virtually nothing about his father. His first contact with the "Western World" came at the age of twenty-five, when for the first time he was permitted to visit the land of his ancestors, Hungary. To Vladimir communist Hungary of those days appeared like a "never-never" land. His eyes were opened, and thereafter his primary goal was to leave the "Soviet Paradise," along with his family. His dream was fulfilled in 1974, when he defected to Canada and established himself as a noted engineer and a Canadian citizen.

Following his retirement Vladimir Rott decided to write the history of his family, and more specifically the sad story of his father, whom he last saw in 1938, when he was only three years old. His multivolume memoirs appeared in three languages, Russian, Hungarian and English. Since the appearance of his books, he has been traveling around, giving lectures about Stalin's Russia and the destructive communist ideology. In his introduction to his book, he has this to say about that land of mass terror:

My Canadian listeners ... found my conclusions about the future of communism very extreme, pessimist, and anti-Soviet. My Jewish listeners were very upset when I said that Stalin was much worse than Hitler. I was compelled to explain to them that Hitler destroyed the Jews, Gypsies and the physically handicapped simply because they were Jews, Gypsies and physically handicapped. The innocent victims of the Stalin period, however, were many more. On top of that, 
everyone in the country knew, irrespective who he was - war hero, hero of labor, prominent scientist, able theater director, noted military officer, or simple worker - that he could be arrested any day on the basis of a denunciation, or for absolutely no reason whatever. After that a torturer could force him to confess anything or everything. And then he was destroyed. People lived for decades in an atmosphere of continuous terror. They did not sleep all night, waiting for the knock on the door. Arrests always took place during the night. A husband did not dare to be truthful to his wife, and old friends were unable to trust each other. Stalin was able to achieve all this, by reshaping the mind of his own people. ${ }^{39}$

\section{A Few Most Recent Gulag-Books}

In the course of the past two years a number of books have appeared about aspects of the Soviet Gulag. These include Timothy Snyder's Bloodlands (2010), ${ }^{40}$ Norman Naimark's Stalin's Genocide (2011), ${ }^{41}$ Stephen Cohen's The Victims Return (2010), ${ }^{42}$ Paul Hollander's From the Gulag to the Killing Fields $(2007),{ }^{43}$ and Anne Applebaum's Iron Curtain: The Crushing of Estern Europe (2012). ${ }^{44}$ All of these volumes add to our knowledge of the Soviet Gulag.

In connection with the above, one must mention that some three decades ago the US Navy discovered the remnants of a Gulag camp on Wrangell Island in the Arctic Sea. This three-thousand square mile island was discovered in 1881 by Americans, and it has has been in US possession ever since. Americans hardly ever visited this remote ice-covered island until the 1980s, when they discovered that during and after World War II it was the site of several Soviet Gulag camps. According to Avraham Shifrin these remote camps were populated primarily with non-Soviet prisoners. He believes that one of these camps was also the place of exile for Raoul Wallenberg (1912-1947/1960s), the Swedish diplomat who saved many thousands of Hungarian Jews during the last phase of the war. One of the ex-prisoners who survived and settled in Israel, Emil Moshinski, stated that in 1962 he personally met Wallenberg in one of these Gulag camps. ${ }^{45}$

\section{The Position of Hungarian Gulag Prisoners}

American Gulag research concentrates almost exclusively on the study of the institution of the Gulag as it relates to the citizens of the Soviet Union. How they lived and survived in the Gulag, what happened to those who survived after Stalin's death, and how they reintegrate into Soviet society. At the same time these researchers hardly mention the many hundreds of thousand (perhaps millions) of non-Soviet citizens - among them Hungarians - who were taken to these labor 
camps to perform slave labor in the reconstruction of the Soviet Union. This lack of attention to non-Soviet citizens applies to most of the major books on the Gulag. Based on this recognition we are certain that the fate of these unfortunate non-Soviet prisoners will only be treated by their fellow nationals, and in some instances not even by them. (This is so because there are still many Marxist historians who idolize Stalin and his cohorts.)

Anne Applebaum's work - although comprehensive - has only a few scattered references to Hungarians, primarily on the basis of the privately published memoirs of George Bien (1927-2005). In the early part of 1945 the sixteen-year old George Bien was arrested along with his fifty-three year old father, who was a noted cardiologist. The elder Bien died within a few months. George survived, but he had to spend ten years in the far eastern province of Kolyma, where he survived because of the intervention of a kind nurse. George Bien was repatriated to Hungary in 1955, and then - taking advantage of the the Hungarian Revolution of 1956 - he left his homeland and emigrated to the United States. Four decades after his emigration George decided to write his memoirs, largely on the basis of various personal papers and letters that survived his repatriation. His memoirs first appeared in Hungarian in 1997, and then in an English translation in 2003, under the title: Lost Years. A Hungarian Student's Ten Years in the Siberian Gulag. Kolyma 1945-1955. It was this work that caught the attention of Anne Applebaum, on the basis of which she incorporated a few sentences about the Hungarian Gulag prisoners. $^{46}$

Based on the above it is safe to conclude that unless Hungarian scholars decide to write the story of the Hungarians on the Gulag, it will never be written. In that case the suffering and horrendous existences of the captive Hungarians in the Gulag will be gradually forgotten. It will slowly evaporate and then disappear, along with the remnants of the Gulag camps themselves. This is precisely what we - my wife and I - would like to avoid. Through our scholarly activities we hope to preserve the memories of those Hungarians who lived, suffered, and many of whom died in one of Stalin's ghastly penal colonies. ${ }^{47}$

\section{Notes}

1 Delivered in Hungarian on April 17, 2011 as my inaugural lecture to the Hungarian Academy of Sciences. Delivered in English at the International Gulag Symposium, University of Miskolc, Hungary, April 11-13, 2012.

Tamás Stark, “A szovjet fogolyszedés néhány kérdése a magyar állampolgárok körében" [A Few Questions Concerning the Collection of Prisoners from among Hungarian Citizens], in Magyar kényszermunkások és politikai rabok a Szovjetunióban a II. világháború után [Hungarian Forced Laborers and Political Prisoners in the Soviet Union after World War II] (Budapest: Petit Real Könyvkiadó, 2000), 45-59; quotation from p. 45. 
2 Ágnes Gereben, “A Gulag megitéléséről” [Assessing the Gulag], manuscript, 1.

3 Denial of the Holocaust is punishable in the following sixteen countries: Austria, Belgium, Czech Republic, France, Germany, Hungary, Israel, Lichtenstein, Latvia, Luxemburg, Poland, Portugal, Romania, Spain, Slovakia. Switzerland. Two of these countries - France and Hungary - also punish Gulag-denial. See: http://en.wikipedia.org/wiki/Holocaust_ denial\# Harry_Elmer_Barnes

4 On David Irving, see http://en.wikipedia.org/wiki/David_Irving

5 Christopher Hitchens, "Free speech über Alles. Even for David Irving," in Wall Street Journal, 2006. February 23, A16.

6 The authors' interview with Magdolna Rohr, later Mrs. Károly Pintér, Budapest, October 30 2003.

7 I have followed this procedure in all of my classes, "Shaping of the Modern World", at Duquesne University ever since the fall of 2003.

$8 \quad$ Alan Besancon, Le malheur de siécle. Sur le communisme, le nazisme, et l'unicité de la Shoah (Paris: Librairie Arthéme Fayard, 1998). In writing this article I used the English version of this work: A Century of Horrors. Communism, Nazism, and the Uniqueness of the Shoah, translated and introduced by Ralph C. Hancock and Nathaniel H. Hancock (Wilmington, DE: ISI Books, 2007), ix.

9 Besancon, 6.

10 Besancon, 96.

11 Paraphrased by Paul Hollander, Political Pilgrims. Travels of Western Intellectuals to the Soviet Union, China, and Cuba (New York: Oxford University Press, 1981), 173.

12 Hollander, Political Pilgrims, 2.

13 On Robert Conquest see: http://en.wikipedia.org/wiki/Robert_Conquest

14 Robert Conquest, The Great Terror: A Reassessment: 40th Anniversary Edition (New York: Oxford University Press, 2007).

15 "Source List and Detailed Death Tolls for the Twentieth Century Hemoclysm." See http://necrometrics. com $/ 20 \mathrm{c} 5 \mathrm{~m} . \mathrm{htm}$

16 Anne Applebaum's relevant comments were as follows: "The Gulag and the Holocaust belong in the same category of historical events." See the DVD Siberia. How the East Was Won (A\&E Television Network, 2004).

17 The biographies of these victims of Stalin can be found on the Internet.

18 The text of this study can be found on the Internet: http://clogic.eserver.org/2005/furr.html

19 On Anne Applebaum see: http://en.wikipedia.org/wiki/Anne_Applebaum

20 On Shifrin see: http://www.conservapedia.com/Essay:_Avraham_Shifrin:_KAL_007_Researcher

21 On Thubron see: http://en.wikipedia.org/wiki/Colin Thubron

22 Colin Thubron, In Siberia (New York: Harper Colins, 1999), 41.

23 On Szálkai see: http://en.wikipedia.org/wiki/Zoltan_Szalkai/, and http://www.gulag.hu/ szalkai.htm

24 The book originally appeared in French: Le livre noir du communisme. I have used the English translation: Black Book of Communism. Crime, Terror, Repression. By Stéphane Courtois, Nicolas Werth, Jena-Louis Panné, Andrzej Paczkowski, Karel Bartosek, Jean-Louis Maragolin (Cambridge, MA: Harvard University Press, 1999), 4.

25 On Nanci Adler and her book, see: http://www.eurospanbookstore.com/index.asp?

26 On Oleg Khlevniuk see: http://en.wikipedia.org/wiki/Oleg_Khlevniuk

27 The most significant work on this topic is Paul Hollander's above cited work Political Pilgrims. See also Steven Béla Várdy, “A nyugati értelmiség árulása: Sztálin-imádatuk a Gulag haláltáborok árnyékában” [The Treachery of the Western Intellectuals. Stalin's Adoration by 
Western Intellectuals under the Shadow of the Gulag Death Camps], in Valóság (Budapest), vol. 50, no. 10 (October 2007), 16-25.

28 On this Ukrainian "Holocaust" known as "Holodomor" [death by hunger] see: Robert Conquest, The Great Terror. A Reassessment (New York: Oxford University Press, 1990); Miron Dolot, Execution by Hunger. The Hidden Holocaust (New York: W. W. Norton \& Co., 1985); and the article "Holodomor" in the Wikipedia which summarizes the recent debate over the number of victims of this artificial famine created by Joseph Stalin. Scholarly estimates run from 2.4 to 7.5 million deaths. Other claims stretch from 4.5 to 10 million.

29 In addition to the above-cited works, see also: Steven Béla Várdy and Agnes Huszár Várdy, "Cannibalism in Stalin's Russia and Mao's China", in East European Quarterly, vol. 41, no. 2 (June 2007), 223-38; S. B.Várdy and A. H. Várdy, "Kannibalizmus a szovjet Gulag rabszolgatáboraiban" [Cannibalism in Soviet Gulag Slave Labor Camps], in Valóság, vol. 49, no. 5 (May 2006), 14-34.

30 Paul Hollander, ed., From the Gulag to the Killing Fields (Wilmington, DE: ISI Books, 2007).

31 Hollander, From the Gulag to the Killing Fields, 255-77.

32 Some of these memoirs and interviews are listed in the following works: Steven Béla Várdy and Agnes Huszár Várdy, Stalin's Gulag: The Hungarian Experience (Napoli, Italy: Universita degli Studi Napoli L'Orientale, 2007), 143-75; and S. B. Várdy and Agnes Huszár Várdy, Magyarok a Gulag rabszolgatáboraiban [Hungarians in the Slave Labor Camps of the Gulag] (Budapest: Kairosz Kiadó, 2007), 287-306.

33 Tim Tzouliadis, The Forsaken. An American Tragedy in Stalin's Russia (New York: The Penguin Press, 2008).

34 On Fort-Whiteman see: Glenda Elizabeth Gilmore, Forgotten Revolutionaries.The Radical Roots of Civil Rights, 1919-1950 (New York: Norton Publishers, 2008); and also the anonymous article "The Revolutionary Life and Death of Comrade Lovett Fort-Whiteman" to be found on the Internet: http:/ /www.google.com/search?q=Lovett+Fort-Whiteman\&hl=en\& source $=$ hp \&ie $=$ ISO-8859- $1 \&$ btnG $=$ Search

35 On Ambassador Joseph E. Davies see: http://en.wikipedia.org/wiki/Joseph_E._Davies

36 About Lattimore's pro-communist activities see: John T. Flynn, The Lattimore Story (New York: The Devin-Adair Co., 1953).

37 On the other deceived Westerners see: Paul Hollander, Political Pilgrims, and Tim Tzouliadis, The Forsaken.

38 Vladimir Rott, A sors ellenében. I. Szenvedésböl vigasz [In Defiance of Fate. I. Joy from Sadness] (Budapest: Széphalom Könyvmühely, 2008), 29.

39 Vladimir Rott, A sors ellenében, 8-9.

40 Timothy Snyder, Bloodlands. Europe between Hitler and Stalin (New York: Basic Books, 2010).

41 Norman M. Naimark, Stalin's Genocides (Princeton, NJ: Princeton University Press, 2010).

42 Stephen F. Cohen, The Victims Return: Survivors of the Gulag after Stalin (New York: Publishing Works, 2010).

43 Paul Hollander, ed., From the Gulag to the Killing Fields. Personal Accounts of Political Violence (Vilmington, DE: ISI Books, 2007).

44 Ann Aplebaum, Iron Curtain: The Crushing of Eastern Europe, (2012).

45 Concerning Wrangell [Vrangel] Island and the fate of Raoul Wallenberg see: Avraham Shifrin, The First Guidebook to Prisons and Concentrations Camps of the Soviet Union (Uhldingen/Seewis: Stephanus Edition, 1980), 248 and 346.

46 György Zoltán Bien, Elveszett évek. Egy magyar diák raboskodása a GULÁG kelet-szibériai lágereiben. Kolima 1945-1955, 2nd ed. (Budapest: Püski Kiadó, 2000); and its English ver- 
sion: George Z. Bien, Lost Years. A Hungarian Student's Imprisonment in the Gulag in Kolyma, Eastern-Siberia 1945-1955 (Fairfax, VA: Self-Published, 2003). There is also an earlier edition of the Hungarian version, published by the author in 1997.

47 The visible results of our efforts include the already cited two books: Stalin's Gulag: The Hungarian Experience (2007), and Hungarians in the Slave Labor Camps in the Gulag (2007, 2nd ed., 2010, in Hungarian), as well as about a dozen scholarly and popular articles. 
